\title{
KÜLTÜREL DÖNÜşÜMLER VE TEKNOLOJiK GELIŞMELER iLIŞKISINDE JENERATIF SANAT
}

\author{
GENERATIVE ART IN RELATIONS BETWEEN CULTURAL TRANSFORMATIONS AND \\ TECHNOLOGICAL DEVELOPMENTS
}

\author{
Engin Güney ${ }^{*}$, Serpil Uysal ${ }^{* *}$
}

\section{Öz}

Bilim, sanat ve teknoloji gibi kültürel dinamikler her çağda dönüşüm geçirmekte ve yeni dengeler oluşturmaktadır. 21. yüzyılda sanat, bilim ve teknoloji entegrasyonu yaşamın her alanını etkilediği gibi sanata da yeni yorumlar kazandırmaktadır. Geçmişten günümüze bir sanat üretim yöntemi olarak varlık gösteren jeneratif sanat, çağın bilimsel bilgisini ve yeni medya teknolojilerini kullanmaktadır. Bu çalışmada zamanla değişen kültürel yapılanmalar ve teknolojik gelişmeler paralelliğinde jeneratif sanatta gerçekleşen dönüşümlerin ilişkisini ortaya koymak amaçlanmıştır.

Günümüzde yeni medya sanatı kapsamında değerlendirilen jeneratif sanat oldukça eski bir üretim yöntemidir. Çalışmada, jeneratif sanatın tarihsel süreç içerisinde geçirdiği dönüşüm, sanat üretim felsefesi, jeneratif sistemlerin tasarımı incelenmiş ve farklı dönemlere ait jeneratif eserlerle sürecin gelişimi irdelenmiştir. Yeni medya teknolojileriyle entegre olan jeneratif sanat, günümüzde otonom sistemleri ve üretim süreciyle sanatçısına ve izleyicisine yeni kültürel eşikler oluşturmaktadır. Gelecekçi teknolojilerle etki alanını giderek artıracağı öngörülen jeneratif sanatın yaratacağı olası dönüşümlere vurgu yapılmış; toplum, sanatçı, sanat ve eğitim kurumları için önemine değinilmiştir.

Anahtar Kelimeler: Jeneratif Sanat, Jeneratif Tasarım, Yeni Medya Sanatı, Kodlama, Algoritma Sanatı.

\section{Abstract}

Cultural dynamics are transforming and creating new balances in every age. In the 21st century, the integration of art, science and technology brings new interpretations to art. Generative art uses the scientific knowledge and new media technologies in this era. In this study, it is aimed to reveal the relationship between transformations taking place in generative art in paralel with the changing cultural structures and technological developments.

Although generative art is considered within the scope of new media art, it is a very old production method. In this study, the transformation of generative art in the historical process, the philosophy of art production, the design of generative systems are examined. Today, generative art creates new cultural thresholds for the artist and the audience. It is predicted that generative art will increase its impact with future technologies. The importance of generative art for society, artists, art and educational institutions is emphasized.

Keywords: Generative Art, Generative Design, New Media Art, Coding, Algorithm Art.

\footnotetext{
Araşırma Makalesi // Başvuru tarihi: 02.10.2019 - Kabul tarihi: 13.12.2019.

*Dr. Öğr. Üyesi, Ondokuz Mayıs Üniversitesi,Güzel Sanatlar Fakültesi, Resim Bölümü, engin.guney@omu.edu.tr, https://orcid.org/0000-0001-6555-6729.

** Ondokuz Mayıs Üniversitesi, Güzel Sanatlar Enstitüsü, Sanat ve Tasarım Anasanat Dalı, serpil.uysal11@gmail.com, https://orcid.org/0000-0002-7605-9696.
} 


\section{Giriş}

21. yüzyıl, bilim, sanat ve teknoloji entegrasyonuyla biçimlenmektedir. Yeni medya teknolojileri bu entegrasyonun bir ürünü olarak yaşamının her alanında insana dokunmaktadır. Kültürel dinamiklerin dönüştüğü bu yeni ortamda insanın kendini ifade biçimi olan sanatta geçmişte benzeri görülmemiş bir değişim geçirmektedir. Sanatın resim, müzik, heykel, fotoğraf gibi farklı türlere ayrıldığı geleneksel türlerden; fütürizm, kavramsal sanat çalışmaları, fluxus, minimalizm gibi 20. yüzyıl sanat akımlarından ve enstalasyon, performans sanatı, video sanatı gibi sanat ifade yöntemlerinden farklı olarak yeni medya sanatında; terkibin tasnife tercih edildiği bir yaklaşım görülmektedir. Sanatın tanımı, amacı ve sanat eserinin taşıdığı anlam yeniden oluşturulurken sanat izleyicisi de bu dönüşüm içerisinde farklı roller üstlenmektedir. Veri sanatı, robotik sanat, net sanatı, fraktal sanat, yazılım sanatı, dijital enstalasyon gibi farklı sanat türlerini kapsayan yeni medya sanatı sanatçısına yeni ortamlar, araçlar ve teknikler sunmaktadır. Jeneratif sanatta da benzer biçimde farklı disiplinlere ait bilimsel bilgiden ve yeni medya araçlarından yararlanılmaktadır. Günümüzde jeneratif sanat; yöntemi, süreci, sistemi ve üretilen sanat eserleriyle yeni medya sanatı içerisinde anılsa da geçmişten günümüze bir sanat üretim yöntemi olarak varlık göstermektedir.

\section{Geçmişten Günümüze Jeneratif Sanat}

"Generative" sözcüğü Proto -Hint-Avrupa kök ailesinden gelen ve "doğurma, yaratma” anlamında kullanılan "gene"- kökünden türemektedir. "Generate" kelimesi "üreme, yayılmaya veya çoğalmaya dair" anlamlarında kullanılırken sonuna eklendiği "eğilimli olma, yapma, hizmet etme" gibi anlamlara gelen "-ive" son ekiyle "üretken" anlamındaki "generative" kelimesini oluşmaktadır. "Generative", dilbilimde bir kelime olarak ilk defa 1959'da kullanılmıştır (Online Etymology Dictionary, 2019).

Philip Galanter, jeneratif sanatın ne olduğu sorusunun, kendisine "kör adamlar ve fil" hikâyesini hatırlattığını ifade etmektedir (Galanter, 2003:2). Kör adamların her biri filin farklı bir parçasına dokunarak fili tanımlasalar da yapılan tanımların hiçbiri bir diğerine benzememektedir. Jeneratif sanat, geçmişten günümüze yaşanan değişimlerle kendini güncelleyen, bulunduğu dönemin teknolojisinden yararlanan bir sanat üretim yöntemi olarak zaman içinde farklı tanımlamalarla ifade edilmektedir. Yapılan farklı tanımlamalar üzerinden 
geliştirilen tümevarımsal bir yaklaşım, jeneratif sanatın ne olduğunun anlaşılması konusunda bütüncül bir sonuca ulaştırabilir.

Alan Dorin ve Jon McCormack, jeneratif sanatı "genotip" ve "fenotip" kavramlarıyla tanımlamaktadır. Organizmanın taşıdığı genetik yapı olan "genotip", sanatçının oluşturduğu kodu temsil etmektedir. Genetik kodun dış faktörler etkisiyle ortaya çıkan görünüşü olan "fenotip" ise sanatçı tarafından tasarlanan sistemin ürettiği şaşırtıcı formları ifade etmektedir. Aynı "tür"ün bireylerinin birbirinden farklı görünümlere sahip oluşu gibi jeneratif çalışmalarda birbirinden farklı ve benzersizdir (Dorin ve McCormack, 2001:240). Dorin ve McCormack'a ait jeneratif sanat tanımı Monro'ya göre hatalıdır (Monro, 2007:3). “Genotip" terimi, bir organizmanın çevre faktörleri ile birlikte fenotipini tayin eden genetik yapıyı ifade etmektedir (TDK, 1998). Monro, "genotip"in "yapay yaşam terminolojisi"nde de genotip ve fenotip kavramlarını beraber içerdiğini belirtmekte ve bu nedenle Dorin ve McCormack'ın "genotip" kullanımının problemli olduğuna dikkat çekmektedir (Monro, 2007:3).

Jeneratif Sanat Konferansı başkanı Celestino Soddu, jeneratif sanatı; “algoritma, yazılım gibi araçların kullanıldığı bir sanat üretim fikri" olarak tanımlamaktadır (Soddu, 2005). Marius Watz'a göre, jeneratif bir sanat eseri, "sanatçının kendisi dışında kurallara dayalı sistemlerle" üretilmektedir. Kurallara dayalı bu sistemlerin “üretkenlik yönü” baskındır (Petersen, 2005).

"Jeneratif Sanat Grubu" kurucusu Neagu, jeneratif sanatın üretim sürecinin yeni formların birbirine temasıyla başladığını ifade etmekte ve jeneratif sanatı "üst üste binme, geri çekilme ya da ilerleme gibi karmaşık varyasyonlarla" başlangıç formunun yeni bir tasarıma dönüştüğü "geometrik soyutlama formu" olarak tanımlamaktadır (Galanter, 2003:16; Soban, 2006). Erkin, jeneratif sistemlerin "geri dönüşümsüz" olarak gerçekleşmesini doğada görülen "metamorfoz" kavramıyla açıklamaktadır: "Kuruyan yaprakta veya solan bir gülde görülen süreç geri dönüşümsüzdür. Metamorfoz gerçekleşmiş bir kelebeğe tırtıl diyemeyiz. Tüm bunlar geri dönüşümsüzlüğü ifade eder. Dönüşüm için gereç olup kimliklerine geri dönüşemez" (Uysal, 2018:133). Başlangıç değerlerinin transformasyona uğradığı jeneratif sistemlerde süreç geri dönüşümsüz olarak gerçekleşmekte ve başlangıç değerlerine benzemeyen yeni sanatsal formlar oluşturulmaktadır. Greg Jalbert (1998)'e göre oluşan yeni formlar "evrimsel süreçlere" benzer bir yöntemle oluşmaktadır. Evrimsel süreçlerle olası birçok etkinin öngörülemez sonuçları 
oluşurken jeneratif sistemlerin geliştireceği tasarımlar sanatçısını dahi şaşırtmaktadır. Jalbert (1998), eserde kullanılan jeneratif yöntemlerin "duygusal etki, estetik, kişiselleştirme, ticari çekicilik ve propaganda" gibi çeşitli sebeplere bağlı olarak tercih edilebileceğini belirtmektedir.

Jeneratif sanat kavramı Watz'a göre bilgisayar teknolojileriyle birlikte başlamış ve sanatçıların sanat üretim materyali olarak kodlamayı tercih etmesiyle popülerliği giderek artmıştır. LeWitt, Riley, Vasarely gibi sanatçılara ait çalışmalar, jeneratif sanatın günümüzdeki dönüşümünü anlayabilmek adına önemli referanslardır (Petersen, 2005). Kavramsal üretimler, minimalist ve fluxus yaklaşımları, evreni, insanı ve sanatı algılamaya yönelik geliştirilen düşünüler jeneratif sanat anlayışının oluşumunda önemlidir. Watz, bilgisayar tabanlı üretimlerin "üretkenlik yönü" baskın olsa da bilgisayar aracılı̆̆ıyla gerçekleştirilen her uygulamanın jeneratif sistem olmadığını belirtmektedir (Petersen, 2005). Watz'ın bilgisayar teknolojileriyle sınırlandırdığı alanın aksine Adrean Ward, jeneratif oluşum süreçlerini "bilgisayar ya da makine tarafından matematik ya da çeşitli talimat kullanılarak otomatikleştirilmesi" olarak tanımlamaktadır (Soban, 2006). Jeneratif sanatın bilgisayar teknolojilerinden oldukça eski bir geçmişe sahip olduğu yönünde pek çok görüş bulunmaktadır.

Jeneratif sanata dair yapılan çeşitli tanımlara ve yaklaşımlara tümevarımsal bir perspektif sunan Galanter, kapsayıcı bir tanım oluşturmuştur: Jeneratif sanat, "sanatçının bir dizi doğal dil kuralları, bilgisayar programı, makine veya bir dereceye kadar otonom harekete geçen buluşun, eserin tamamlanmasına ya da sonuçlanmasına katkıda bulunduğu her hangi bir sanat pratiğidir" (Artut, 2018; Galanter, 2003:4, 2016; Gülderen, 2017; Güney, 2014; Monro, 2007; Phon-Amnuaisuk ve Panjapornpon, 2012; Tempel, 2017). Jeneratif sanat, tarih boyunca farklı sanat akımlarından sanatçılar tarafından farklı amaçlarla uygulanmış ve tanımlanmıştır (Galanter, 2003:16; Soban, 2006). Galanter'e ait jeneratif sanat tanımında sanatın neden bu şekilde yapıldığına ya da içeriğine dair bir açıklama bulunmamaktadır. Ona göre, jeneratif sanatın bir akım olarak kabul görülmesi, soyut sanatın bir alt kümesi olması, bilgisayar teknolojileriyle birlikte başlaması, sanat ifade biçimi olarak değerlendirilmesi gibi çeşitli yaklaşımlar, jeneratif sanatın kapsamını daraltmaktadır. Jeneratif sanat, "modernizm, postmodernizm ya da diğer "izm”lerin çok öncesinden beri varlık göstermekte ve "jeneratif" kelimesi en basit haliyle "sanatın bir alt kümesi"ni oluşturmaktadır (Galanter, 2003:15-19). Bu 
yaklaşımla, jeneratif sanatın, bir sanat akımının iddia edemeyeceği kadar büyük ve üretim yöntemlerinin kısıtlanamayacak şekilde geniş bir kavram olduğu sonucuna varılmaktadır. "“Jeneratif" ifadesi bu potansiyeli gerçekleştirebildiği ölçüde tüm sanatı kapsamaktadır ancak bu amacından uzaklaştığında kullanışlıı̆ı̆ını da yitirmektedir" (Galanter, 2003:4).

Bir sanat akımı olmanın ötesinde sanatın bir alt kümesi olarak tanımlanan jeneratif sanat, sanat üretim yöntemi olarak bilgisayarın keşfinden çok önce varlık göstermiş ve gelişimi günümüze kadar devam etmiştir. Galanter, tarihin erken dönemlerinde sanat üretmek için kullanılan basit araçların jeneratif sanat üretim teknikleriyle benzerlik gösterdiğini ve jeneratif sanatın şaşırtıcı bir şekilde sanat kadar eski olabileceğini savunmaktadır (Galanter, 2003:13). Cape Town'da 1999 ve 2000 yılları arasında bulunan tarihi eser ve üzerindeki tasarım Galanter'in düşüncesini desteklemektedir. Christopher Henshilwood tarafından bulunan 70.000 yıldan daha eski bir döneme ait olduğu tespit edilen taş üzerinde okre kırmızısıyla çizilmiş kusursuz üçgen ızgaralardan oluşan bir tasarım yer almaktadır (Görsel 1). Henshilwood, taş üzerindeki çapraz tasarımın kenarlarında aniden sonlanmış olması nedeniyle desenin geniş bir yüzey üzerinde daha karmaşık soyut bir tasarım olabileceğini belirtmektedir (Dunham, 2018).

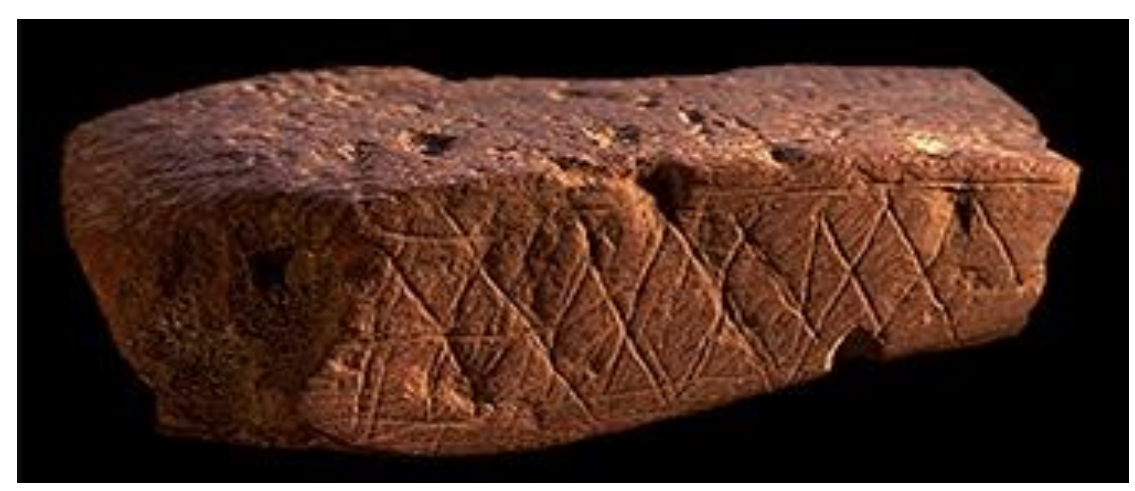

Görsel 1. Blombos Mağarası'nda Christopher Henshilwood tarafından bulunan 77.000 yıl öncesi döneme ait tarihi eser.

Galanter, 70.000 yıl öncesine ait bu eserin jeneratif sanat örneklerinden olduğu şeklinde tartışmalı bir görüş belirtse de bu gibi oymalar ilkel insanların "bilişsel yeteneklerini" ve "soyut geometri düşünce becerisini" ortaya koymaktadır. Bulgular jeneratif sanatın sanat kadar eski olduğuna yönelik kesin bir kanıt oluşturmasa da geçmiş dönemlerde form üretiminde simetriden ve soyut geometrik biçimlerden yararlanıldığı görülmektedir. Istvàn Hargittai, Magdolna Hargittai ve Peter S. Stevens gibi yazarlar tarafından, ilkel insanlar tasarladıkları 
tekstil ürünlerinde geometrik desenlerin kullanıldığını, noktayı merkez alarak büyüyen ve tekrarlanan, yüksek simetri özelliği gösteren tasarımlar içerdiği belgelenmiştir (Galanter, 2003:13). Galanter, taş üzerine kazınmış olan yapının; soyut geometrinin ustalıkla kullanıldığı İslam soyut sanatına ait bezemeleri ve Escher'in simetri özelliği içeren resimlerini çağrıştırdığını belirtmektedir (Galanter, 2003:13). İslam soyut sanatında mimariden kıyafetlere, duvar süslemelerine, gündelik eşyalara kadar her türlü alanda yoğun geometrik motiflerden yararlanılmıştır. İspanya'daki Elhamra Sarayı, 13. yüzyıl İslam soyut sanatının ve mimarisinin en güzel örneklerindendir. Odalarında ve avlu planlarında V2 ve V3 gibi karmaşık sayılarla tasarlanan oranlar ve matematiksel formüllere dayanan üretken süreçler kullanılmıştır (Karlığa, 2013) (Görsel 2). Soyut bitkisel formların kusursuz tekrarlarında farklı simetri gruplarından yararlanılmıştır (Yetkin, 1993). Öteleme, dönme, yansıma, kayma-yansıma gibi çeşitli simetri türleri ve süreklilik kurallarıyla sonsuza kadar devam edebilecek hissi veren desenler üretilmiştir (Sarısaman, 2013).

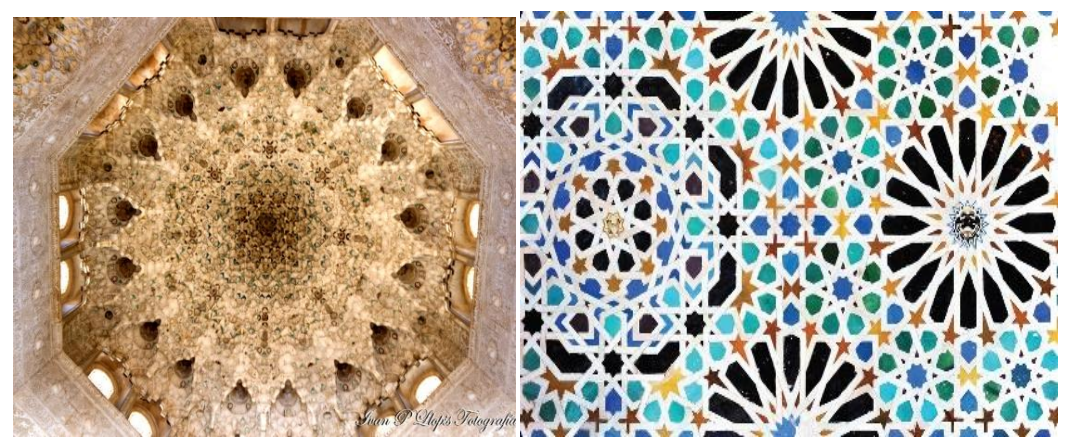

Görsel 2. 13. yüzyıl Elhamra Sarayı bal peteği formundaki tavan işlemesi ve bezemelerdeki radyal motifler, Granada, İspanya.

Desenlerde kullanılan soyut geometrik tasarımlar ve katı cisimlerin atom dizilimleri arasında benzerlikler bulunmaktadır. 19. yüzyılda Arthur Moritz Schoenflies ve Evgraf Stepanovich Fyodoroy adlı matematikçilerin bezemelerin iki boyutlu kristal yapılarını inceledikleri çalışmalarında 17 farklı simetri grubu keşfedilmiştir. 1924 yılında George Pólya tarafından kristal yapılar ve düzlem bezemelerinin uyumlu olduğu kanıtlanmıştır. "Kristalografik sınıflandırma" tekniğiyle düzlemdeki bezemelerin hangi simetri grubuna ait oldukları tespit edilebilmektedir. Matematikçi Edith A. Müller, Elhamra Sarayı'na ait bezelemelerde 17 farklı simetri grubundan 13'nün bulunduğunu belirtmektedir (Erbudak, 2018). San Marco Bazilikasına 
ait 48 farklı resim üzerinde yapılan çalışmada ise 9 farklı simetri grubu tespit edilmiştir (Erbudak ve Erinekçi, 2018). 20. yüzyıl ressamı ve grafik tasarımcısı Maurits Cornelis Escher'e ait bir grafiği "p3m1" olarak isimlendirilen simetri grubuyla benzeşim göstermektedir (Erbudak, 2018). Escher, Elhamra Sarayı ve La Mezquita Camii gibi karmaşık sayılarla tasarlanan oranların kullanıldığı İslam soyut sanatı ve mimarisinden etkilenmiş ve çalışmalarında parça-bütün ilişkisine, geometrik formlara, doğanın matematiksel prensiplerinin keşfine yönelmiştir (İstanbulsanatevi, 2016).

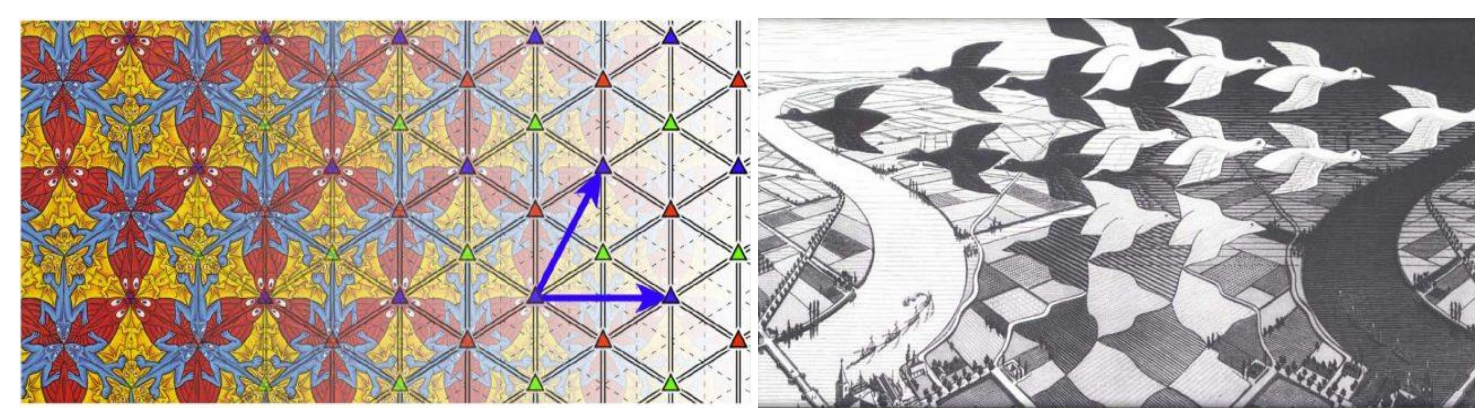

Görsel 3. Solda Maurits Cornelis Escher'e ait bir grafiğin kristalografik incelemesi, Sağda Gündüz ve Gece, 1938, Siyah ve Gri Gravür, 39x67 cm.

Galanter, Escher'in sanatsal çalışmalarını oluşturduğu dönemde bilgisayar henüz keşfedilmemesine ve matematik eğitimi konusunda eksikliklerinin bulunmasına rağmen algoritmalardan yararlandığını belirtmektedir (Galanter, 2003:13). Escher, F. Haag ve G. Pólya gibi matematikçilerin makaleleri ve çalışmalarından etkilenmiş, Roger Penrose gibi matematikçilere tasarımlarıyla ilham vermiştir. Farklı simetri kurallarını kullandığı eskizlerinde "düzlemin düzenli bölünebilmesi" ve "düzlem doldurma" gibi çalışmalar gerçekleştirmiştir (Görsel 3). Uyumlu paralel kenarlardan oluşan ağ yapıları, karşıt renk ve figür dualitesiyle kurguladığı figür ve zemin ilişkileriyle "Gündüz Gece", "Şelale", "Sonsuz Merdiven" gibi eserlerinde karşıtların bitişikliğini sorgulamıştır (Schattschneider, 2015).

Endüstri dönemine kadar yüksek simetri özelliği gösteren tasarımların erken dönem jeneratif sanatın ilk örneklerini oluşturduğu söylenebilir. Dokuma endüstrisinde desen tasarımlarının delikli kartlarla otonom olarak üretilmesi sonrası Charles Babbage'nin “Analitik Makine" icadı, Charles Hollerith'in arka arkaya delen delikli kartların makineye aktarılmasıyla oluşturulan "programlama" sayesinde otonom üretim süreçlerinde dokuma sektöründen 
enformasyon çağına doğru ilerleme kaydedilmiştir. Bu süreç, bilgisayarların üretileceği dönemin zeminini oluşturmuştur (Öztürk, 2012). Galanter (2003:13), gelişen bu süreçten hareketle "jeneratif sanatın oluşumu için bilgisayara ihtiyaç duyulmadığını aksine jeneratif yöntemler sayesinde bilgisayarın icat edildiğini” vurgulamaktadır. 20. yüzyıl sonlarına doğru dönüşen bilimsel paradigmalarla birlikte sanatçı, sanat kavramı, sanatın konusu ve sanat eseri de farklı sorgulamalar, deneyimler ve yorumlarla dönüşüm geçirmiştir. Robert Spahr, yüzyılın başından sonuna doğru Marcel Duchamp, John Cage, George Brecht, Steve Reich, Sol LeWitt gibi sanatçıların alanlarında yeniyi, yapılmamış olanı tasarlayarak günümüz jeneratif sanatına biçim verdiklerini belirtmektedir (Spahr, 2018). Durağanlık, sessizlik, akışkanlık, hareket, sanatçıdan bağımsız gelişen süreçler, deneysel çalışmalar ve arayışlar sanatçılar tarafından sanat üretim sürecine dâhil edilmiştir. Kullanılan amaçlar doğrultusunda değişen jeneratif teknikler ve farklı yaklaşımlarla jeneratif sanat, kapsamı giderek genişleyen bir sanat pratiğine dönüşmüştür.

Jeneratif sanat, yöntemleri, amaçları ve uygulama çeşitliliğiyle oldukça zengindir. Günümüz jeneratif çalışmaların temellerini 20. yüzyıl sanatçılarının farklı arayış ve sorgulamaları oluşturmuştur. Duchamp, 1913'te “3 Standart Stopaj” çalışmasıyla bir metrenin ne kadar olduğunu gibi mutlak kabul edilen kavramlar üzerine yeni sorgulamalar ve tanımlar geliştirmiştir (KhanAcademy, 2015). Besteci John Cage'in 1946'da icat ettiği “prepared piano (hazırlanmış piyano)", piyano telleri arasına yerleştirilen cisimlerden oluşmaktadır (Elivar, 2015). Cisimler sayesinde notanın vuruş seslerini manipüle eden sanatçı eş zamanlılığı ve rastlantısallığı üretim sürecine dâhil etmiştir. Kavramsal sanatçı ve avangard besteci George Brecht, 1959'da “Drip Music (Damlama Müziği)" adlı çalışmasıyla doğada ve insan yaşamında var olan sürekliliği ve değişimini ifade etmektedir (Gümüş, 2019). Rastlantısal süreçler müzik, edebiyat, görsel sanatlar gibi hemen hemen her alanda deneyimlenmektedir (Soban, 2006). Carl Andre, Mel Bochner ve Paul Morgenson gibi minimalist sanatçılar, çalışmalarında basit matematiksel ilkelerden yararlanmaktadır. Kavramsal sanatçı Sol LeWitt, 1960’lı yılların başında hacim, sıralama, varyasyonlar, durağanlık gibi sistemler ve kavramlar üzerinde durmakta ve çalışmalarında geometrik formlardan yararlanarak tekrarlı desenler üretmektedir (Galanter, 2003:18). LeWitt'in duvar çizimlerine dair oluşturduğu talimatlar, asistanları tarafından uygulanmaktadır. Taslakların ve kararların önceden belirlendiği ve sanatçıdan bağımsız 
gerçekleştirildiği bu üretim "fikrin sanat yapan bir makine" haline dönüşmesi şeklinde bir yaklaşım oluşturmuştur (Galanter, 2003:18; LeWitt, 1980) (Görsel 4). Aynı talimattan her defasında farklı varyasyonların üretilmesi, jeneratif sanatın "üretici yönü baskın" oluşuyla benzerlik göstermektedir.
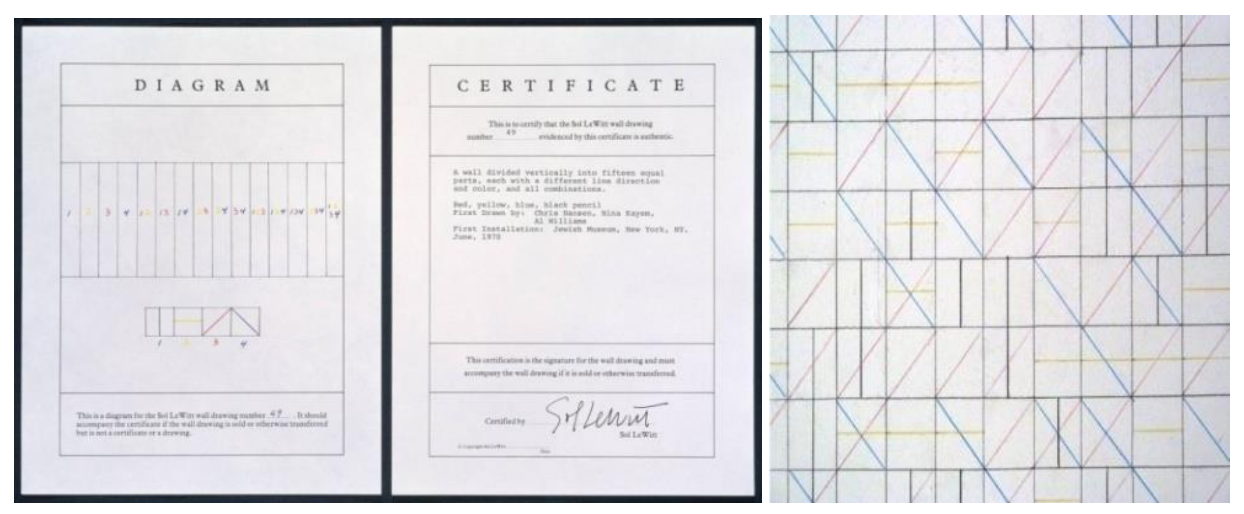

Görsel 4. Sol LeWitt'e ait boyama talimatı ve Wall Drawing \#33, 1970.

Hans Haacke ışık, sıcaklık, hava değişimleri ve yer çekimi gibi fiziksel kuvvetleri kullanarak sistemler tasarlamaktadır. Stabil olmayan, kendi içerisinde dönüşüm geçiren ve tahmin edilemez sonuçlar üretilen bu tarz çalışmalar ilerleyen dönemde jeneratif sanatın üretim süreçlerinde deneyimlenmiştir. "Condensation Cube" adlı çalışmada, sıcaklığın etkisiyle bir miktar suyun hal değişimlerinin gerçekleştiği "minyatür bir hava sistemi” tasarlanmıştır (Görsel 5).

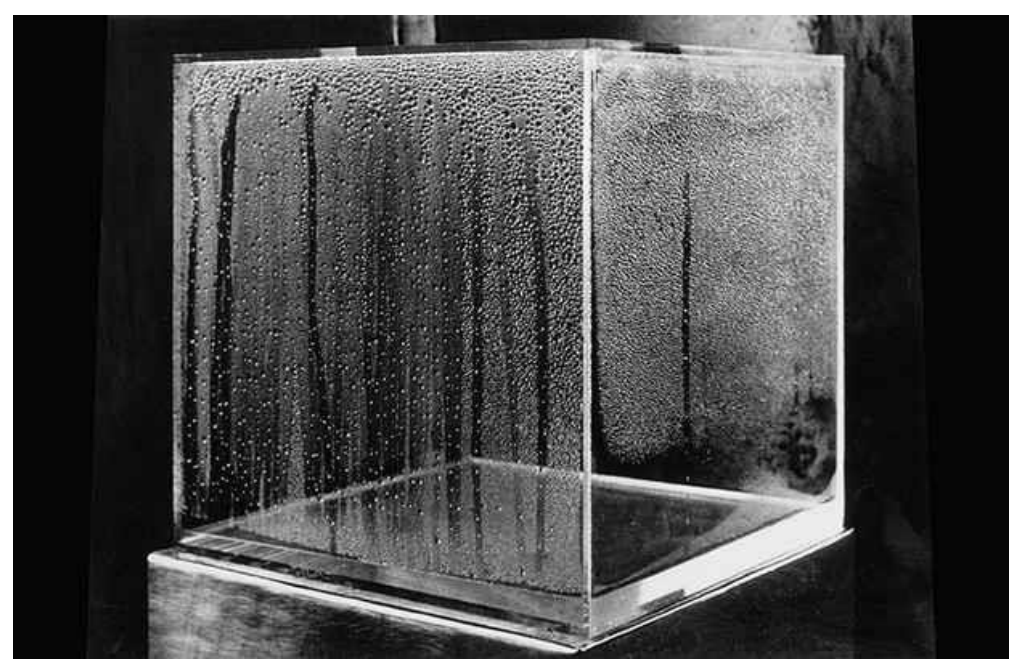

Görsel 5. Hans Haacke, Condensation Cube, 1963-1965, Tate Gallery. 
Galanter'e göre, Hans Haccke'in 1965 yılında yayınladığı bildirisi jeneratif sanatçılar için bir "manifesto" niteliğindedir. Bildiride; rastlantısallığın, hareketliliğin ve dönüşümün sağlandığı sistemlerin geliştirilmesinin önemi vurgulanmış, sanatçıya; izleyiciyle etkileşime geçen eserler üretmesi ve izleyicinin sanat üretim sürecinin bir parçası haline dönüştürülmesi konusunda yönlendirmeler yapılmıştır (Galanter, 2003:18).

\section{Yeni Medya Sanatı Olarak Jeneratif Sanat}

Yöntemleri, amaçları ve uygulama çeşitliliği açısından oldukça engin olan jeneratif sanat, 21. yüzyılda rastlantısal teknikleri ve şaşırtıcı sonuçları bilgisayar teknolojileri aracılığıyla gerçekleştirmektedir. Bilgi çağında üretilen sanat eserlerinde bilimsel bilgiden ve dijital dönüşümden yararlanılmaktadır. Dadaist, fütürist, minimalist sanat ve kavramsal sanat gibi farklı akımların felsefesinden ve dijital teknolojilerin ortaya çıkardığı tekniklerden beslenen jeneratif sanatçı, geçmişten günümüze sürdürülebilir yaklaşımlar oluşturmuştur. Candaş Şişman, günümüz sanatının geleneksel sanat türlerinde olduğu gibi ya da etkileşimli, kuşatıcı, süreç bazlı, katılımcı şeklinde işlevsel kategorizasyonlar oluşturmanın doğru olmadığını belirtmektedir. Ona göre hiçbir grup tek başına, yeni medya sanatı adı altında yapılan üretimi karşılamamaktadır (Yeğinsu, Şişman ve Saraç, 2018). Terkibin tasnife tercih edildiği bu tür çalışmalarda sanatçı, geçmiş dönemlerin kavramlarını yeniden sorgulamakta ve yorumlanmaktadır. Sanat eseri, sanatçı ve izleyici ilişkisi dönüşüm geçirmiştir. Sanatçı, sanat üretiminde matematik denklemleri, evrimsel hesaplamalar, fonksiyonlar, yapay zekâ, kural tabanlı algoritmalar, genetik algoritma, fraktal üretim teknikleri ve kodlama gibi farklı teknik araçlardan yararlanmaktadır (Phon-Amnuaisuk ve Panjapornpon, 2012:51). Dijital teknoloji, sanatçı için hem bir araç hem de sanat üretim ortamıdır. Sanatçı eserlerinde evreni, evrimsel süreçleri, insanı sorgularken izleyenin de sanat üretim sürecine katıldığı, bilgisayar teknolojilerinin sanatçının enstrümanı olduğu bir üretim ortamı oluşturulmaktadır. Sanatçı bu projelerde bir bilim insanı titizliğinde araştırmalarını sürdürürken yazılımcı, tasarımcı ve farklı uzmanlıklara sahip insanlarla birlikte çalışmaktadır. Türkkan, günümüz sanatçısının aynı zamanda iyi bir araştırmacı olması, sanat üretim sürecinde farklı deneyimlere dokunması ve farklı projelere yönelmesi gerektiğini ifade etmektedir (Uysal, 2019:135). 
"Yaratıcılık anlayışı", bilim ve sanatın sentezlendiği bir alanda gelişim gösterebilmektedir. Bilgisayar teknolojileri de bu alana uyumlu araçlardır (Soban, 2019). Jeneratif sanat, farklı disiplinleri harmanlayan, bilgisayar teknolojilerini kullanan, farklı fikir ve düşüncelerin oluşturabileceği tüm sonuçların, otonom tasarlanmış sistemlerce üretilmesine imkân veren kolektif bir alan oluşturmaktadır. Bu alan içerisinde sanatçının enstrümanları kodlar, algoritmalar ve çeşitli üretim teknikleridir. Casey Reas, "kod denizi" haline getirilen platformlarda sanatçıların, tasarımcıların ya da programcıların ürettikleri eserlere ait kaynak kodlarının ve çalışma bilgilerinin paylaşıldığını ifade etmektedir. Sanatçı bu kolektif alanda kendi tasarımını geliştirebileceği gibi farklı çalışmalardan da ilham almaktadır. "Processing, Github, VVVV, openFrameworks, Cinder ve Max.4" gibi yazılım ortamları bu paylaşım özgürlüğünü desteklemekte ve sanatçı, tasarımcı, programcı ya da meraklısına hedefleri doğrultusunda katkı sağlamaktadır (Galanter, 2016:163; Reas vd., 2018).

Bilgisayarların keşfi sonrasında Frieder Nake, Michael Noll gibi bilgisayar bilimcileri ve Vera Molnár, Harold Cohen gibi sanatçılar tarafından oluşturulan yazılımlar ilk defa sanat üretimi için kullanılmıştır (Daniele ve Song, 2019:3). Yazııımlar sayesinde sanatçı çeşitli araçlarla sistem tasarlamakta ve üretim sanatçıdan bağımsız bir şekilde sistem tarafından gerçekleştirilmektedir. Nake ve Noll, eserlerinde rastgele sayı algoritmaları kullanan ilk dijital sanatçılardır. Noll, Modrian'ın "Composition with Lines (Çizgilerle Kompozisyon)" adlı çalışmasını yeniden yorumlamış "Gaussian Quadratic" adlı eserini üretmiştir (Görsel 6). Düzenli bir çizgiyle başladığı çalışmanın boyutlarını ve konumlarını rastgele sayıların "Gauss dağılımını" kullanarak taklit etmiştir (Galanter, 2016:161). Georg Nees'in, 12 karenin dönüş hareketinin kademeli olarak artırıldı̆̆ı "Schottter" adlı çalışması bilgisayar tarafından üretilen ilk jeneratif eserler arasında görülmektedir (Görsel 6). Bailey, çalışmaya elle 10 kare daha eklemenin on saate yakın zaman alabileceğini belirtmektedir. Kod ile gerçekleştirilecek ufak bir dönüşümle binlerce kare tasarlanabilmektedir. Vera Molnár bilgisayarların bir oda büyüklüğünde olduğu dönemlerde jeneratif çalışmalar üreten bir sanatçı olarak yazılımların sağladığı bu imkânları, "bir sanatçının zihnindeki görüntüyü tam anlamıyla yansıtabilmesi" olarak tarif etmektedir. Molnár'a göre, "soğuk olarak nitelendirilen bir makine, insana dair yaratıcılığın ve derinliğin ifade edilebilmesine yardımcı araçlardandır" (Bailey, 2018). 
SDÜ ART-E

Güzel Sanatlar Fakültesi Sanat Dergisi

Aralık'19 Cilt:12 Sayı:24

ISSN 1308-2698
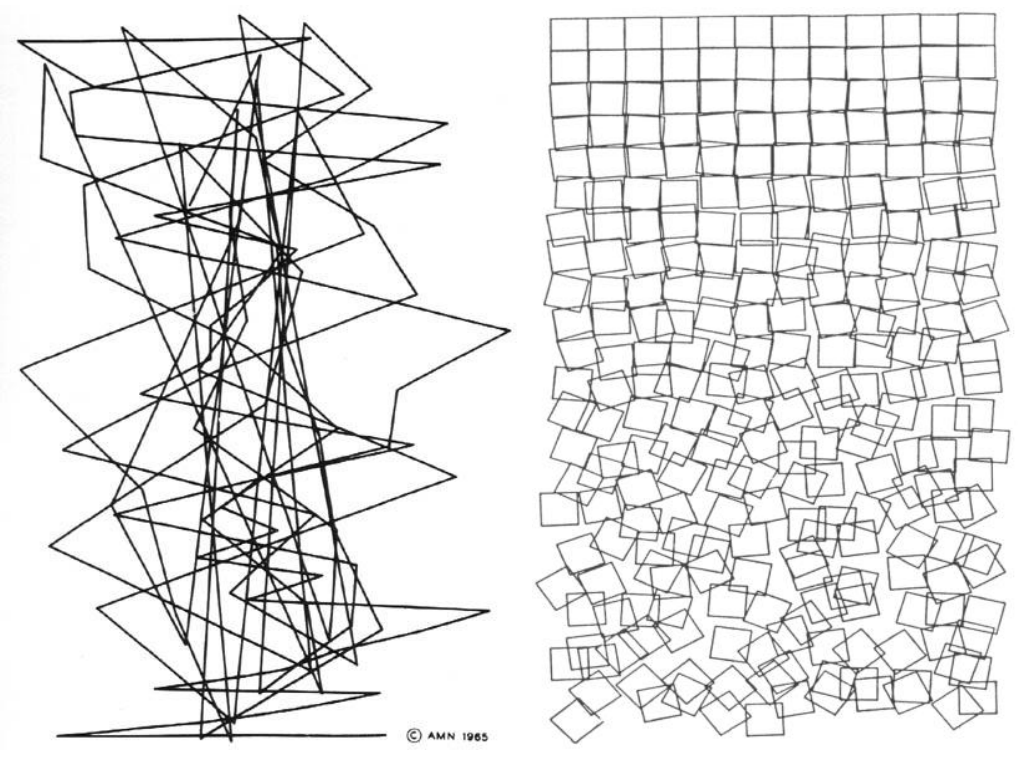

Görsel 6. Solda Michael Noll, Gaussian Quadratic, 1965 ve Sağda Georg Nees, Schotter, 1968.

Bilim insanı Benoit Mandelbrot, bilgisayar ortamında denklemlerin iterasyonuyla oluşturduğu sonuçları görselleştirmiştir. Kullandığı Julia denkleminin milyonlarca kez tekrarlanan işlemlerle ve renklendirilme çalışmalarıyla Julia ve Mandelbrot kümeleri keşfedilmiştir. Görüntü büyütüldüğünde sonsuza kadar kendini tekrar eden bütüne benzer parçalar oluşmaktadır. Parçanın bütüne ait öz bilgiyi taşıdığı bu tür örüntüler fraktal oluşturmaktadır. Scot Draves, William Latham gibi sanatçılar tarafından yeni medya teknolojilerinden yararlanarak fraktal özellikte sanatsal formlar üretilmiştir. Latham, dijital teknolojileri ve biyoloji, matematik, fizik ve sosyal bilimler gibi farklı disiplinleri sanat üretim sürecine entegre ederek fraktal özellikler gösteren "organik formlar" tasarlamıştır (Güney, 2014:146) Görsel 7). Bilgisayarlarda ekran koruyucusu olarak kullanılan “Electric Sheep” adlı fraktal özellikteki animasyonlar Scot Draves tarafından yazılım ve fraktal tekniklerin kullanıldığı fraktal sanat çalışmalarındandır (Cınbarcı, 2015:39) Görsel 7). Farklı matematik formüllerinin, fonksiyonların, basit geometrik şekillerin veya belli kuralların iterasyonu, renklendirme ve farklı parametre düzenlemeleriyle fraktal yapılı iki boyutlu ve üç boyutlu tasarımlar ve yapay yaşam formları üretilmektedir. Yazılımların kullanılarak elde edildiği bu jeneratif çalışmalar, "Fraktal sanat", "Algoritmik Sanat" ya da "Yazılım Sanatı" olarak da tanımlanabilmektedir (Gülderen, 2017:77). 


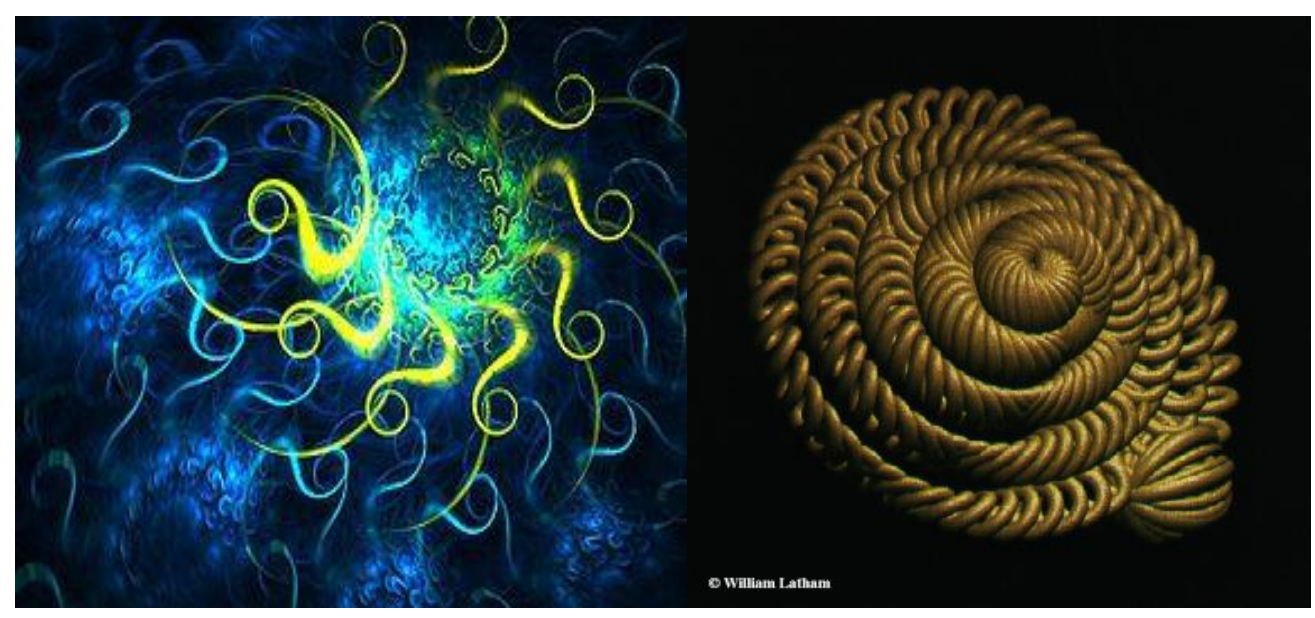

Görsel 7. Solda Scot Draves, Electric Sheep, Dijital Fraktal Çalışma, Sağda William Latham'a Ait Dijital Fraktal Yapılı Organik Form.

Soddu, jeneratif sanatının "fikir, kod oluşturma, süreç ve sonuçların seçimi" şeklinde dört evreden oluştuğunu belirtmektedir. Fikir, kod oluşturma ve sonuçların seçimi insanın öngörebileceği ve düzenleyebileceği alanlardır. Reas, kodlarla sanat üretmenin kodları kişiselleştirmekle mümkün olacağını belirtmektedir (Reas, 2011). Tasarlanan düşünceler önce basit eskizlere ardından kodlara dönüştürülmektedir. Kullanılan program içerisinde aşamalı olarak geliştirilen kodlar sayesinde basit düşünceler sanatsal formlara dönüştürülmektedir. Reas, kodlarla tasarlanan sistemin sanatçısını bile şaşırtan sonuçlar ürettiğini belirtmektedir (Reas vd., 2018). Ozan Türkkan, jeneratif sistemlerin kod ve algoritmalar gibi tam olarak tanımlı kurallarla oluşturulmasına ve aynı kurallardan her defasında benzersiz sonuçlar çıkmasına dikkat çekmektedir. Ona göre jeneratif sistemler "bağımsız bir organizma" gibi çalışmaktadır (Uysal, 2019:135):

Doğadaki gibi bir elma tohumunu toprağa koyduğunuzda her seferinde elma ağacı çıkar ama her bir ağaç birbirinden farklıdır. Bu süreç jeneratif sanatın da temelini oluşturur... Sanatçı çekirdeği ve bu çekirdeğin içinde barınan genetik yapıyı kurar ve süreci başlatır. Süreç içinde algoritma bazı noktalarda kendi kararlarını verir ve sonuç hiç öngörülemeyen bir noktaya gidebilir. Bu süreçte olasılıklar ve değişkenlerin kombinasyonları o kadar çoktur ki her bir sonuç bir öncekinden farklı ve biricik olur. Doğa bunu var oluş surecinin her anında her aşamasında yapıyor.

Jeneratif sanatın üçüncü evresi olan süreç aşaması kod, zaman ve makine işbirliğiyle insandan bağımsız olarak gelişmektedir (Soban, 2019). Sanatçıya ait fikirler ve kararlar "programlama dilinin kontrol yapısı" ve sürece ilişkin "değiştirilebilen parametreler" gibi kontrol kategorileri sayesinde dâhil edilebilmektedir (Phon-Amnuaisuk ve Panjapornpon, 2012:44). 
Süreç aşaması çeşitli algoritma türleriyle tasarlanabilmektedir. Bu süreç içerisinde jeneratif sisteme verilen basit bir veri, algoritmanın özelliğine göre "yineleme, seçilim, yönelim ve yeniden düzenleme" gibi çeşitli dönüşümlere uğramakta ve neye benzeyeceği öngörülemeyen anlık çalışmalar üretilmektedir (Creators, 2012). Bu evre, Sol LeWitt'in talimatları doğrultusunda asistanları tarafından yapılan duvar çizimlerini anımsatmaktadır. Jeneratif eser sanatçıdan bağımsız olarak asistanlar tarafından üretilirken yeni medya teknolojileri sayesinde yine sanatçıdan bağımsız bir biçimde sanatçı tarafından tasarlanmış sistem tarafından üretilmektedir. "Düşüncenin sanatın gerçekleştirilmesini mümkün kılan bir makineye dönüşebileceği” düşüncesi Casey Reas'ı "kavramsal sanatın tarihi, sanat olarak yazılım fikriyle ilişkili midir?” sorusuna yönlendirmiştir. Reas, LeWitt'in 3 ayrı çalışmasına ait oluşturduğu kodları yazılım diline dönüştürerek 26 adet çalışma üretmiştir (Bayraktar, 2011:13). 20. yüzyılda yeniden sorgulanan algılar, düşünüler ve kavramlar, 21. yüzyılda dijital dönüşümle birlikte yeniden yorumlanmış ve jeneratif sistemler aracılığıyla farklı biçimler kazanmıştır. Artut (2018:340)'a göre soyut ortamlarda gerçekleşen bu süreç; hızlı tekrarlar, rotasyon, renk, konum ve ölçek gibi parametre değerlerinin etkisiyle üretilen ışıltılı formların sürekli tekrarlanan ve hızla değişen yapıları "organik bir uyum” oluşturmaktadır. Soddu (2018:74).'ya göre, üretilen formlarda parçaların birbirleriyle ve bütünle ilişkisinde bulunan ritim olgusu, özgünlük ve uyum jeneratif sürecin bel kemiğini oluşturmaktadır. Jeneratif sistemlerle oluşturulan çalışmalarda tamamlanan bir eser yeniden sisteme beslenebilmekte ve eklentiler oluşturularak eserin dönüşümü gerçekleştirilebilmektedir. Reas'a ait 2005 yılında tasarlanan "Network" adlı talimatın kaynak kodu kullanılarak 2009 yılında "Process 4" adında bir enstalasyon çalışmasına dönüştürülmüştür. "Process 4" adlı çalışmanın yeniden biçimlenmesi, düzenlenmesi ve aydınlatma, aşındırma gibi çeşitli manipülasyonların uygulanmasıyla 2011 yılında "Immuring" adlı bir enstalasyon üretilmiştir (Uysal, 2019:114) (Görsel 8). 


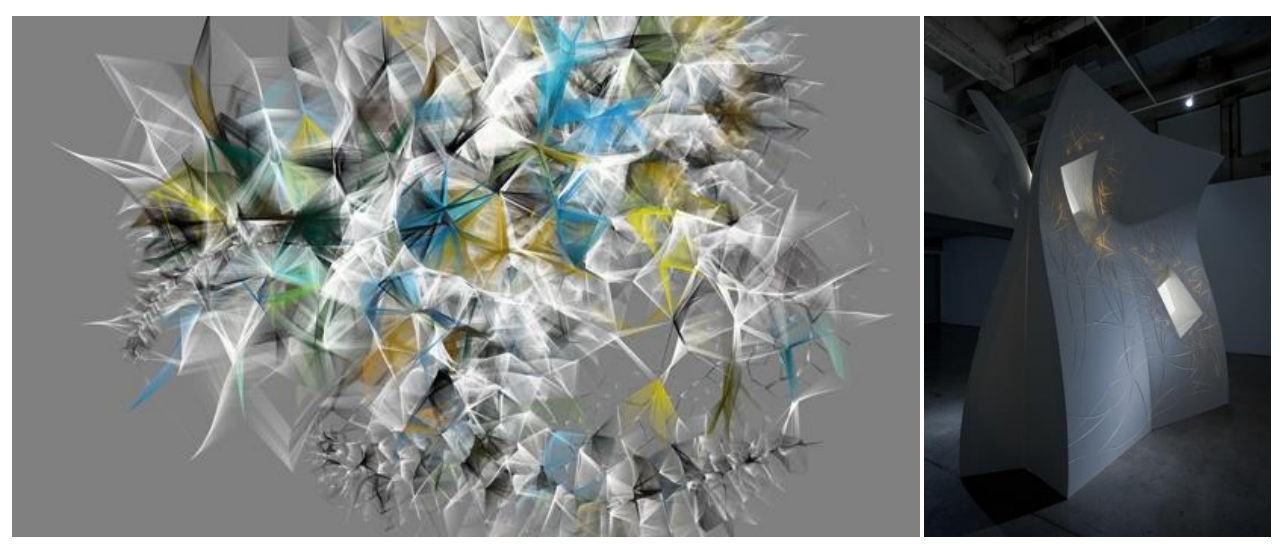

Görsel 8. Casey Reas, Solda Network A, Process 4, 2009, dijital çalışmasından anlık görüntü ve sağda Immuring, 2011, Enstalasyon.

Sanatçı Jessica Rosenkrantz ve sanatçı Jesse Louis-Rosenberg çalışmalarında doğanın kendine has fraktal formlarından ilham almaktadır. Doğadaki fraktal oluşumların altındaki bilimsel bilgiyi kullanan ekip, bitkilerin büyümesini fraktal üretim tekniklerinden olan Lindenmayer sistemleriyle; yaprakların büyümesi ve çiçeklerin açmasını diferansiyel büyümenin hesaplamalı simülasyonlarıyla tasarlamaktadır. Doğanın biyomekaniğinden yararlanırken "Floraform" ve "Hyphe" gibi farklı türde algoritmalar kullanarak fikirlerini basit kurallar kümesine dönüştürüp modelleyebilmektedir (Görel 9). Soyut heykel, baskı, aydınlatma, takı, yapboz, kinematik kıyafet gibi üç boyutlu yazıcılar ve kesim cihazlarıyla ürettikleri tasarımların ötesinde jeneratif süreçlerin sunduğu sayısız formda tasarımlar elde edilmektedir. Ekip, çalışmaların kaynak kodlarını ortak kullanım lisansı altında açarak tasarımların kişiselleştirilmesine imkân sunmaktadır (Rosenkrantz ve Louis Rosenberg, 2019).
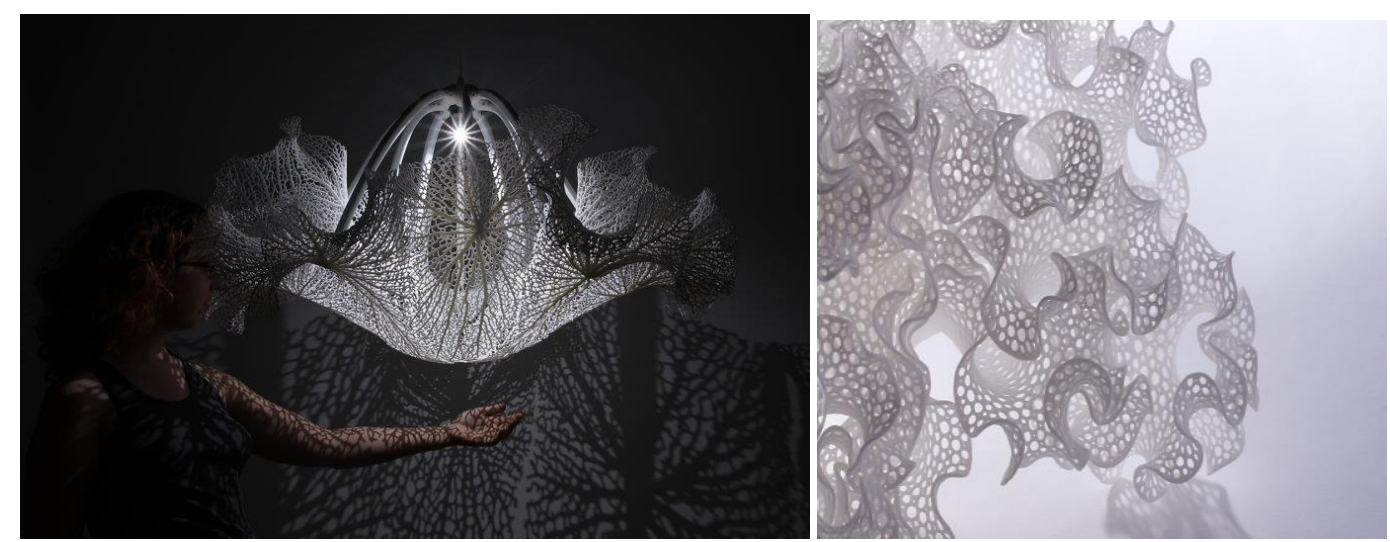

Görsel 9. Rosenkrantz ve Louis Rosenberg, solda Floraform Chandelier, 2017, sağda floraform heykel tasarımı, 2015. 
Yeni medya sanatçısı Ozan Türkkan (2013), jeneratif çalışmalarında farklı algoritma türlerinden, polinom fonksiyonlarından, fraktal üretim tekniklerinden yararlanmaktadır. Çalışmalarında doğum, ölüm ve yeniden doğuş gibi evrimsel süreçleri, zihnin mani ve depresyon süreçlerinde deneyimlenen değişimleri, kuantum fiziği, ışık, ses ve frekans gibi fiziksel terimleri bir bilim insanı gibi incelemektedir. Projeler, uzun süren araştırma ve okumalarla felsefi bir altyapı kazanmakta ve gelişmektedir. Galanter, jeneratif sanat sistemlerin tasarımında sanatçının rolüne ve tasarlanan sistemin evrenle olan ilişkisini önemsemektedir:

Jeneratif sanatçı, karmaşık sistemleri kullanarak otonom süreçlerin sonucu olarak bir form oluşturmaktadır. Bu oluşumlarsa dünyayı anlayabilme kabiliyetimizin sınırlarını zorlayıcı örneklerdir. Jeneratif sanatçı bize evrenin üretken bir sistem olduğunu hatırlatmakta ve jeneratif sanatsa, evrendeki yerimizi ve birliktelik anlayışımızı yeniden kazanmamıza olanak sağlamaktadır (Galanter, 2003:19).

Türkkan, "Bipolar Fractal” adlı dijital video çalışmasında, mani ve depresyon anlarındaki geçişleri yansıtmaktadır (Görsel 10). İki durum arasında değişen, artan ve azalan deneyim durumları geometrik mutasyonlar, Rutt Etra benzeri sentezlenmiş fraktal formların dinamik hareketleri ve seslerin frekanslarıyla işlenmektedir (Türkkan, 2013).

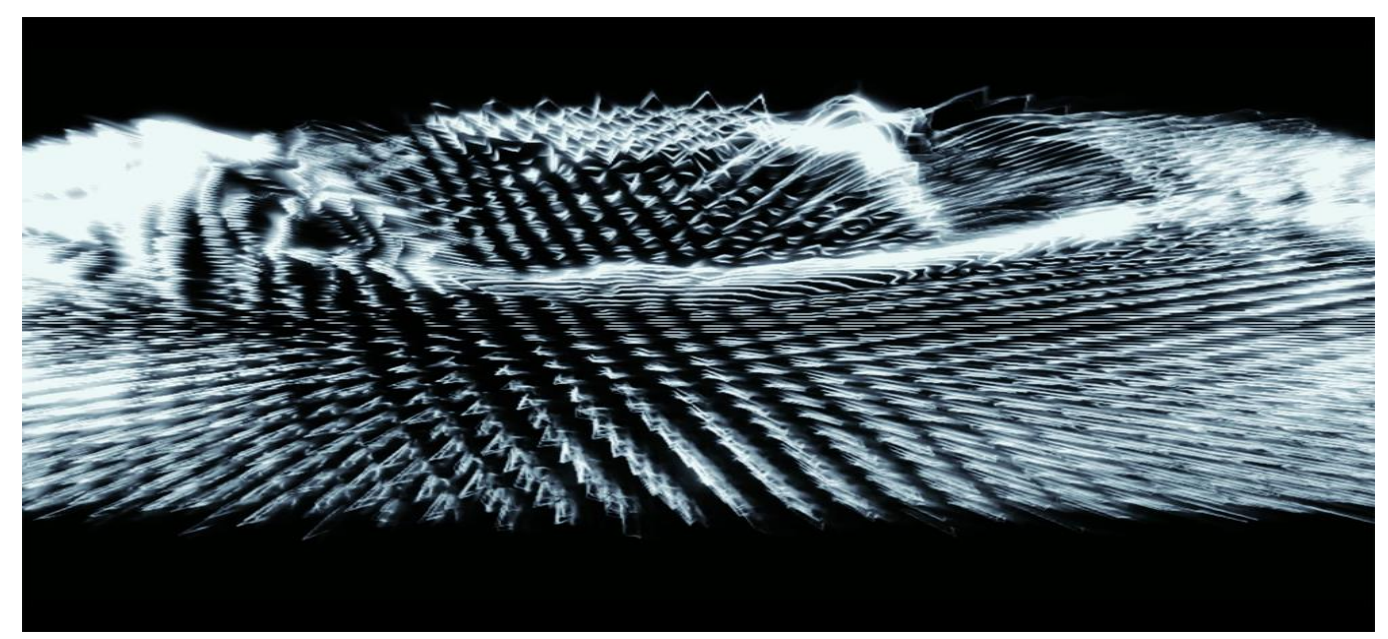

Görsel 10. Ozan Türkkan, Bipolar Fraktal, 2014, dijital video enstalasyon çalışmasından anlık görüntü.

Sanatçı, tasarladığı sistemi ve sisteme ait parametrelerini nasıl oluşturduğunu ifade ederken jeneratif sanatın aslında doğanın kullandığı sistemleri kullandığını belirtmektedir (Uysal, 2019:136): 
Nasıl bir formu tasarlayacağımı; bağırdığında ya da sakinleştiği anda nasıl bir yapıya bürüneceğini ve tüm bu sürecin nasıl bir denge oluşturacağını düşündüm. Sanskritce'de bir söz vardır: "Nada Brahma". Önce sesin, titreşimin yaratıldığını ifade eder. Bu çalışmada ses çok önemli bir parametreydi ve form onu takip ediyordu. Ama süreç içerisinde ses ve form iletişim kurmaya başladıklarında birbirlerini var ediyor: bazen öne çıkarken bazen geride kalıyor ama dengede ilerliyorlar. Aralarındaki iletişim önemliydi. Çığlıkları, boşlukları ve dinginlik hallerini dengeli bir zemine oturtmaya çalıştım. Dalgalanma boyutu oldukça yüksek olsa da her zaman bir denge vardır. Çı̆̆ıı, nefes alma, boşluk, dinlenme, devinim gibi modların ses ile vurgulanması daha etkileyici olmaktaydı. O yüzden dijital seslerin yanı sıra su, rüzgâr, ateş, orman gibi doğal sesler de kullanarak iç içe harmanladım. Karakter ne kadar dijital bir formda olsa da canlı ve organik bir etki yaratmaya çalışım.

Günümüzde bitkinin büyümesi, doğadaki dinamik sistemlere ait davranışlar, makrodan mikroya gerçekleşen farklı fraktal örüntüler bilgisayarlar aracılı̆̆ıyla modellenebilmekte ve geliştirilen üretim teknikleri sanatçılar tarafından otonom sistemlerin tasarımında kullanılmaktadır. Yapay zekâ ve makine öğrenimi de jeneratif sanat çalışmalarında yararlanılan teknolojilerdendir. İlk jeneratif sanat uygulamalarından olan "AARON" 1970'lerde İngiliz ressam Harold Cohen tarafından tasarlanmıştır. Cohen'in kendisine, resim yapan bir asistan olarak tasarladığı Aaron'un yazılımı John McCarthy'nin ürettiği "LISP programlama sistemiyle" gerçekleştirilmiştir (Robotlar Sanat Yapabilir mi?, 2015). Cohen'in resim yapma yöntemleri "kodlara dönüştürülerek" çizimler gerçekleştirilmektedir. Zamanla güncellemeler yapılarak eğitilen yapay zekâ "AARON", Cohen'in sanatsal tavrından oldukça farklı eserler ortaya çıkarmıştır (Çokokumuş, 2012:18; Galanter, 2016:164; Özel Sağlamtimur, 2010:219). Cohen, "özellikle renklendirme konusunda bağımsız olarak hareket ettiğini ancak hiçbir zaman kendi kendine çalışmadığını" belirtmektedir. (Soban, 2006; WiredStaff, 1998).

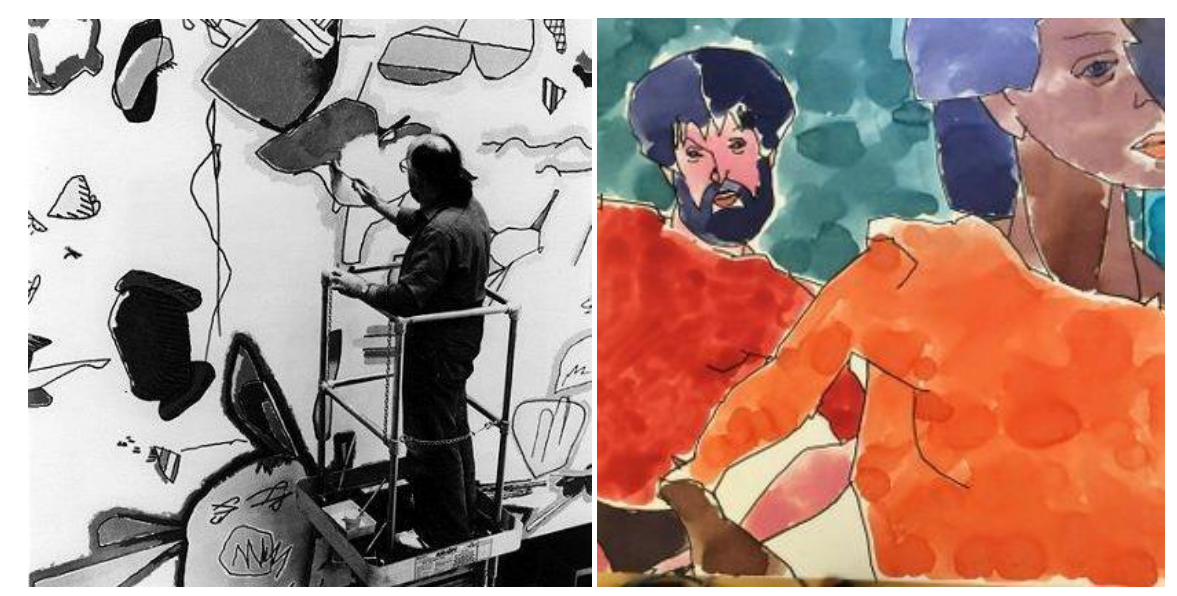

Görsel 11. Harold Cohen'in tasarladığı AARON'a ait 1982 ve 1995 yıllarında üretilen çalışmalar. 
Resim yapan, tasarım gerçekleştiren, beste yapan ya da şiir yazan yapay zekâlar, derin öğrenme ve istatistiğe dayalı yapılarıyla daha önce hiç oluşturulmamış çalışmalar üretmektedir (Edmonds, 2018:5). Bager Akbay'ın 2015 yılında tasarladığı şair robot Deniz Yılmaz otonom çalışan bir sisteme sahiptir. Akbay, CNC makinesinin ucuna bağladığı bir kalemden oluşan tasarımı ilk olarak bir sözlük, vezin ve uyak yapılarıyla ilgili güncellemeler yapmıştır. Ardından açık kaynak kodlarına ulaştığı külliyatı, edebi eserleri ve 12.000 adet şiiri makine öğrenmesiyle sisteme aktarmıştır (Akbay, 2017). Çalışmada, derin öğrenme ağlarının kullanıldığı şiir bilgisi ve şiir istatistiği ile örüntüler oluşturulmaktadır. 2016'da Ebru Yetişkin tarafından derlenen Deniz Yılmaz'a ait ilk şiir kitabı yayınlanmıştır (Akbar, Yetişkin, ve Kaplangı, 2017). Üretilen çalışmaların tasarımcıya ait olduğu görüşünün aksine Akbay’a göre üretilen işler robotun eserleridir çünkü yapay zekâ şiirleri kendi okumakta ve kendisi üretmektedir. Akbay, oluşturduğu çalışmalarda eserlerin insanlara ne anlattığından ziyade insanı zihinsel anlam arayışına yöneltmeyi hedeflemektedir. Ona göre insanın sorgulamaları sonucu anlam üretmesi eserin ne anlattığından daha değerlidir (Güldalı, 2019).

Refik Anadol ve ekibi büyük verileri yapay zekâ ve derin öğrenme algoritmaları kullanarak görselleştirmektedir. Oluşan görselleri algoritmaların şiirsel çıktısı olarak ifade eden Anadol, çalışmalarında jeneratif sistemlerden ve otonom süreçlerden yararlanmaktadır. "Veri heykeli" olarak da adlandırılan tasarımlar, yapay zekâ, mimari, kod ve jeneratif sistemler gibi farklı alanlar üzerine düşünce geliştiren ekip tarafından oluşturulmaktadır. 2017 yılında "Arşiv Rüyası", 2018'de "Los Angeles Walt Disney Concert Hall Projesi”, "Evrenin Merkezi”, "Eriyen Hatıralar" gibi pek çok çalışması derin öğrenme algoritmalarının kullanıldığı çalışmalarındandır (Mestan, 2019). Duyguların görselleştirilmesi olarak tanımlanan "Eriyen Hatıralar" adlı çalışmasında, Kaliforniya Üniversitesi nöroloji laboratuvarında insanların hatırlanan duygulara karşı beyinde oluşan sinyallerin elektroensefalografi cihazıyla kaydedildiği veriler algoritmalar aracılığıyla görselleştirilmiştir. 

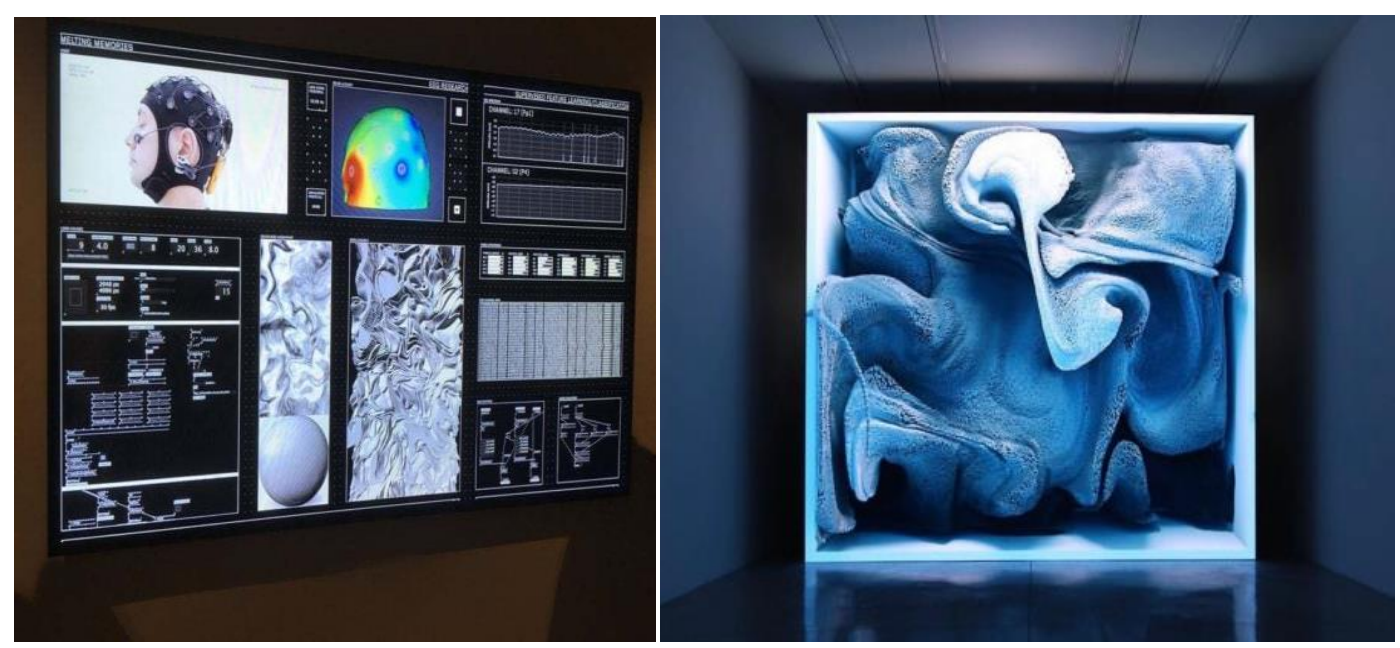

Görsel 12. Refik Anadol, Eriyen Hatıralar, 2018, video enstalasyon.

21. yüzyılda jeneratif sanatçı, bilim ve teknolojiyi sanat üretim sistemine dâhil etmekte, farklı disiplinlerden beslenmektedir. Kullandığı araçlar ve yararlandığı ortamla sanatın sınırlarını aşma gayreti göstermekte; sanatı, sanatçıyı ve sanata dair tüm kavramları dönüştürebilmektedir. Anadol'un, bir makinenin rüya görebilmesinin ya da duyguları ifade edebilmesinin mümkün olup olmadığı sorusu üzerine mevcut teknolojileri kullanarak gerçekleştirdiği çalışmaları, geleceğin dünyasına ait oluşturulabilecek yorumların, üretilecek tasarımların temelini inşa etmektedir. Büyük verilerin farklı amaçlar ve çeşitli tekniklerle enformasyona dönüştürülmesi zamanla daha önemli hale gelecektir. Kına Demirel, geleceğin dünyasında insanların öngörülü değil "veri görülü" olması gerektiğini belirtmektedir (Erden ve Demirel, 2018). Ultav, veriden enformasyona giden yolda geliştirilen yapay zekâ mekanizmalarının etkinliğinin artacağına ve tasarımların kişiselleştirilmesinin önemine vurgu yapmaktadır (Ultav, 2018). Beyin haritalama ve benzetimi, sanal gerçeklik, beyinden alından verilerin enformasyona dönüşmesi ve makine-insan arayüzü gibi pek çok teknoloji gelecekte zihin yükleme süreçlerini oluşturacağı öngörülmektedir (Mutlu, 2015: 193). Beynin yüksek bilişsel süreçlerini artıracak bilinçli beyni dışında kurgulanan dışsal bellekle beyin bilgisayar arayüzü sağlanarak insanın siborg ya da insan ötesi bir varlığa dönüşmesi varsayılmaktadır. Exocortex ile beyin işlemcisi, çıkış ve giriş birimleri ve yazılım sistemleriyle enformasyon işleyebilen bir sisteme dönüşmesi düşünülmektedir (Mutlu, 2015:194). 


\section{Sonuç}

Her dönemde insanlığın bilgiyi kullanma biçimi ve bilgiyi ifade etme yöntemi dönüşüm geçirmektedir. Jeneratif sanatın, geçmişten günümüze yaşanılan dönüşümlerle varlığını sürdürebilmesinin temelinde yenilikçi üretim felsefesi bulunmaktadır. Geçmiş döneme ait jeneratif sanat eserleri incelendiğinde bir sonraki dönemin geliştirdiği sanat ifade yöntemlerinin temelini oluşturduğu görülmektedir. Zamanla kullanılan yöntem ve tekniklerin gelişmesi jeneratif sanatın üretim alanını genişlemektedir. Jeneratif sanat, yeni medya teknolojilerinin şekillendirdiği ortamda yeni yöntem ve farklı süreçlerle geçmişte olduğundan bambaşka bir form kazanmaktadır.

Jeneratif sisteme giren formlar sistem içerisinde transformasyona uğrayarak tasarımcısını bile şaşırtan sayısız varyasyonlara dönüşmektedir. Sistem tam olarak tanımlanmış kural ve talimatlarla tasarlansa da elde edilen varyasyonlar girilen verilerden tamamen farklı, anlık ve biriciktir.

Jeneratif sanat sistemlerinde hedeflenen sonuçların üretilebilmesi için farklı tekniklerden yararlanılmaktadır. Doğanın estetiğinin ardındaki matematiksel dili olan fraktal yapılar, yeni medya teknolojilerinin olanaklarıyla modellenebilir hale dönüştürülmüştür. Bilgisayarlarda problemlere en etkin çözümlerin oluşturulmasında kullanılan algoritmalar, jeneratif sistemlerde sanat üretim araçları olarak kullanılmaktadır. Basit talimatlar dizisinden, koda, çeşitli yazılım dillerine, algoritma türlerine, fraktal üretim tekniklerine ve makine öğrenimine kadar birçok yeni medya aracı sanatçı tarafından tasarladığı jeneratif sistemine amaçları doğrultusunda entegre edilmektedir.

Jeneratif sanatın yaygınlaşması ve gelişmesi için oluşturulan platformlar, yeni öğrenmeye başlayanlardan, tasarımcılara, bilgisayar programcılarına, sanatçılara kadar pek çok farklı uzmanlığa sahip bireylerin kolektif üretim gerçekleştirdikleri ortamlardır. Sanatçı, içinde bulunduğu çağın donanımlarını kullanan, yaratıcılık sınırlarını zorlayan, disiplinler arası araştırmalardan öğrendiklerini sanat üretim sürecinde deneyimleyen, kolektif bilince katkı sağlayan bir rol üstlenmektedir. 
Teknolojinin sanatla bütünleştiği alanda ideolojilerin, büyük şirketlerin ve güç odaklarının, toplumları kontrol edilebilmek ve kişisel verilerden enformasyon üretebilmek için yeni medya teknolojilerini kullanmakta; bu konudaki araştırma ve geliştirme girişimleri desteklenmektedir. Sanatçı, sanat üretim aracı ve ortamı olarak yeni medya teknolojilerinden yararlanırken sorgulayıcı ve eleştirel yaklaşımlar da geliştirmektedir.

Gelecekçi teknolojilerin biçimlendireceği jeneratif sanat çalışmaları, günümüz sanatçılarının yorumlarından ve geliştirdikleri üretim yöntemlerinden beslenerek yeni sanatsal formlar üreteceği düşünülmektedir. Günümüzde gelinen noktada; beyin haritalama ve benzetimi, sanal gerçeklik, beyinden alınan sinyallerin enformasyona dönüşmesi, makine-insan ara yüzü gibi pek çok teknolojinin gelecekte zihin yükleme süreçleri oluşturması beklenmektedir. Jeneratif sanatın yenilikçi üretim felsefesi ve yaklaşımları düşünüldüğünde söz konusu gelişmeler yeni sanat üretim araçlarına dönüşerek insanın kendini ifade biçimi olan sanat yeni sınırlara eriştirecek ve yeni sorgulamalarla mevcut kavramları dönüştürecektir. Bu nedenle sanatçı, sanat eğitimi veren kurum ve kuruluşlar günümüz ve geleceğin sanatını, sanatın genişlemekte olduğu alanı ve bu alanın teknoloji ile bağını kurarak yönelim göstermelidir.

\section{Kaynakça}

Artut, S. (2018). "Futurism Art And Its Significance to Computational Generative Art", XXI. Generative Art Conference, Verona, p.334-342.

Bayraktar, K. O. (2011). Dijital Imge ve Temsili, Yüksek Lisans Tezi, İstanbul: Marmara Üniversitesi, Güzel Sanatlar Enstitüsü, Resim Anasanat Dalı.

Cınbarcı, A. (2015). Fraktal Geometri ve Tekrar Olgusu, Yüksek Lisans Tezi, İstanbul: Yeditepe Üniversitesi,Sosyal Bilimler Enstitüsü, Plastik Sanatlar Anabilim Dalı.

Çokokumuş, B. (2012). "Dijital Ortamda Kültür ve Sanat”, International Journal of New Trends in Arts, Sports \& Science Education, 1(3), s.51-66.

Daniele, A. and Song, Y. (2019). "Al + Art = Human", Artificial Intelligence, Ethics and Society, Association for the Advancement of Artificial Intelligence, Hawaii, p.7.

Dorin, A. and McCormack, J. (2001). "Introduction: First iteration - A Conference on Generative 
Systems in The Electronic Arts", Leonardo, 34(3), p.239-242.

Edmonds, E. (2018). "Algorithmic Art Machines", Arts, 7(3), p.7.

Galanter, P. (2003). "What Is Generative Art? Complexity Theory As A Context For Art Theory", 6th Generative Art Conference, Milan, p.21.

Galanter, P. (2016). "Generative Art Theory", A Companion to Digital Art, ed. Paul C., 1. Edition, Chichester: John Wiley \& Sons, Inc, p.631.

Gülderen, D. (2017). Fraktal Geometri'nin Plastik Sanatlarda Kullanımı, Yüksek Lisans Tezi, İstanbul: Marmara Üniversitesi, Güzel Sanatlar Ensititüsü, Resim Anasanat Dalı.

Güney, E. (2014). Dijital Görsel Kültür ve Yeni Medya Ekseninde Sanatın Değişen Rolü, Doktora Tezi, Samsun: Ondokuz Mayıs Üniversitesi, Eğitim Bilimleri Enstitüsü, Güzel Sanatlar Eğitimi Anabilim Dalı.

Kaya Elivar, D. (2015). "John Cage ve Music Of Changes Adlı Eserin Yorum Analizi”, Uluslararası Sosyal Araştırmalar Dergisi, 8(39), p.6.

Monro, G. (2007). The Concept of Emergence in Generative Art, Master Thesis, Sydney: University of Sydney, Sydney Conservatorium of Music.

Mutlu, M. E. (2015). "Geleceğin Teknolojileri”, Temel Bilgi Teknolojileri II, der. Kurubacak, G. ve Okur M. R., s.168-195. Eskişehir: Anadolu Üniversitesi.

Özel Sağlamtimur, Z. (2010). "Dijital Sanat”, Anadolu Üniversitesi Sosyal Bilimler Dergisi, 10(3), s.213-238.

Phon-Amnuaisuk, S. and Panjapornpon, J. (2012). "Controlling Generative Processes Of Generative Art", Procedia Computer Science, No. 13, p.43-52.

Soddu, C. (2018). "Al Organic Complexity In Generative Art", XXI. Generative Art Conference, Verona, p.68-79.

Tempel, M. (2017). “Generative Art For All”, Journal of Innovation and Entrepreneurship, 6(12), p.14.

Uysal, S. (2019). Fraktal Geometri ve Algoritma İlişkisinde Jeneratif Sanat, Yüksek Lisans Tezi, Samsun: Ondokuz Mayıs Üniversitesi, Güzel Sanatlar Enstitüsü, Resim Anasanat Dalı. 


\section{Internet Kaynakları}

Akbar, B., Yetişkin, E. ve Kaplangı, M. (2017). “Günümüz Sanatı, Bir Başka Kürasyon: Yapay Zeka ve Sanat", https://www.youtube.com/watch?v=oJFm18VxGic\&t=3s, Erişim tarihi: 26.09.2018.

Akbay, B. (2017). "Deniz Yılmaz: Robot Şair", https://www.youtube.com/watch?v=Za6dpKRJoq0 , Erişim tarihi: 01.06.2019.

Bailey, J. (2018). "Why Love Generative Art?", https://www.artnome.com/news/2018/8/8/ why-love-generative-art, Erişim tarihi: 05.02.2019.

Creators, (2012). "How to Draw With Code/Casey Reas", https://www.youtube.com /watch?v=_8DMEHxOLQE, Erişim tarihi: 15.02.2019.

Dunham, W. (2018). "Stone in South African Cave Boasts Oldest-Known Human Drawing", Reuters, https://www.reuters.com/article/us-science-drawing/stone-in-south-african-cave-boa sts-oldest-known-human-drawing-idUSKCN1LS2NY, Erişim tarihi: 20.08.2019

Erbudak, M. (2018). "Bezemelerin Gizemli Simetrisi", Sarkaç, https://sarkac.org/2018/08/ bezemelerin-gizemli-simetrisi/, Erişim tarihi: 16.05.2019.

Erbudak, M. ve Erinekçi, D. (2018). "Bilim ve Sanat El Ele Yeni Boyutlar Yaratıyor", Sarkaç, https://sarkac.org/2018/10/bilim-ve-sanatla-yeni-boyutlar/, Erişim tarihi: 16.05.2019.

Erden, L. ve Demirel, K. (2018). "Veri Şehveti”, Digilogue Summit-Future Tellers'18, (Moderatör: L. Erden), https://www.youtube.com/watch?v=_SgVpWmnI2M\&index=7\&t=0s\&list=PL401z4g 3OAAxdgT2UdoqQMPy_R3QuvMq3, Erişim tarihi: 19.10.2018.

Güldalı, ì. (2019). "Yeryüzleri / 7.Bölüm / Bager Akbay", (Yönetmen: İ. Güldalı) https://www. youtube.com/watch?v=v9bXJzXd_uo, Erişim tarihi: 01.06.2019.

Gümüş, Y. E. (2019). "Fluxus Yönelişi-George Brecht Yaşamı ve İşleri Üzerine Bilgi”, Çağdaş Tiyatroda Arayışlar Ders Notu, https://www.academia.edu/10733889/Fluxus-_George_Brecht, Erişim tarihi: 02.04.2019.

İstanbulsanatevi, (2016). "Maurits Cornelis Escher Hayatı ve Eserleri", https://www.istanbulsanatevi.com/sanatcilar/soyadi-e/escher-mc/maurits-cornelis-escher1898-1972/, Erişim tarihi: 10.01.2019.

Jalbert, G. (1998). "Generative Art: An Exploration of Meaning”, http://www.imaja.com/as/ tonecolor/GenerativeArtExploration.html, Erişim tarihi: 08.01.2019. 
Karlığa, B. (ed.) (2013). "Batıya Doğru Akan Nehir-8. Bölüm: Bilimin Altın Çağı”, TRT, http://www.eba.gov.tr/video/izle/15185e9104bd8ff944131a8077611d615a1492d09c001, Erişim tarihi: 04.04.2019.

KhanAcademy, (2015). "Marcel Duchamp; 3 Standart Stopaj", https://tr.khanacademy.org/humanities/art-1010/wwi-dada/dada1/v/duchamp-3-standardstoppages, Erişim tarihi: 14.02.2019.

LeWitt, S. (1980). "Kavramsal Sanat Üzerine Paragraflar", çev. Nazlı Damlacı, http://www.sanattanimitoplulugu.org/Kavramsal Sanat Uzerine Paragraflar.htm, Erişim tarihi: 15.02.2019.

Mestan, S. (2019). "Refik Anadol ve Duygulardan Heykel Yapmak" https://t24.com.tr/yazarlar /seden-mestan/refik-anadol-ve-duygulardan-heykel-yapmak,22092, Erişim tarihi: 01.06.2019.

Online Etymology Dictionary, (2019). https://www.etymonline.com/, Erişim tarihi: 20.11.2018.

Öztürk, K. (2012). "Dokuma Tezgâhlarından Ana Bilgisayara Delikli Kartlara 250 Yılı", http://www.acikbilim.com/2012/11/dosyalar/dokuma-tezgahlarindan-ana-bilgisayarlara-delikli -kartlarin-250-yili.html, Erişim tarihi: 10.01.2019.

Petersen, T. (2005). "Generative Art Now: An Interview With Marius Watz", http://www.artificial.dk/articles/watz.htm, Erişim tarihi: 15.02.2019.

Reas, C. (2011). "Process Compendium (Introduction)", https://vimeo.com/22955812, Erişim tarihi: 20.08.2019.

Reas, C., Lieberman, Z., McDonald, K., McCarthy, L., ve Anadol, R. (2018). "Açıl Susam Açıl”, Digilogue Summit-Future Tellers'18, mod. Refik Anadol, https://www.youtube.com/watch?v= MI7RdEDS4fI\&index=8\&list=PL401z4g3OAAxdgT2UdoqQMPy_R3QuvMq3, Erişim tarihi: 19.10.2018.

Robotlar Sanat Yapabilir mi?, (2015). https://www.bbc.com/turkce/haberler/2015/09/150923 _robotlar_sanat, Erişim tarihi: 14.01.2019.

Rosenkrantz, J. and Louis Rosenberg, J. (2019). "Nervous System", https://n-e-r-v-o-us.com/ index.php, Erişim tarihi: 16.02.2019.

Sarısaman, M. (2013). "Elhamra Sarayı ve Endülüs'de Bilim”, Hendese Dergisi, http://www.hendesedergisi.com/yazardetay/18-44-elhamra-sarayi-ve-endulusde-bilim.aspx, Erişim tarihi: 06.01.2019. 
Schattschneider, D. (2015). “M. C. Escher'in Matematiksel Yönü”, çev. Osman Altun, https://bilimvegelecek.com.tr/index.php/2015/06/01/m-c-escherin-matematiksel-yonu/, Erişim tarihi: 27.05.2019.

Soban, B. (2006). "Generative Art Definition, Thoughts And Views", http://www.sobanart.com/definitions.asp, Erişim tarihi: 07.01.2019.

Soban, B. (2019). "Generative Art Description By Bogdan Soban", http://www.sobanart.com/ga.asp , Erişim tarihi: 06.01.2019.

Spahr, R. (2018). "Generative Art", Robert Spahr'a Ait Ders Notları, http://www.robertspahr.com/teaching/gen/, Erişim tarihi: 20.05.2019.

TDK, (1998). Türk Dil Kurumu Sözlüğü, http://sozluk.gov.tr/, Erişim tarihi: 18.02.2019.

Türkkan, O. (2013). Bipolar Fractal, http://www.ozanturkkan.com/works/cacophony/, Erişim tarihi: 16.02.2019.

Ultav, C. (2018). "Ne olacak bu insanın hali?”, Digilogue Summit-Future Tellers'18, (Konuşmacı: C. Ultav), https://www.youtube.com/watch?v=e9QWYwin_eE\&index=3\&list=PL401z4g3OA AxdgT2UdoqQMPy_R3QuvMq3, Erişim tarihi: 19.10.2018.

Wikipedia, (2018). "Generative Art", https://en.wikipedia.org/wiki/Generative_art, Erişim: 07.01.2019.

Wired Staff, (1998). "Idées Fortes- Ecological Design”, https://www.wired.com/1998/03/ ideacutees-fortes-2/, Erişim tarihi: 08.01.2019.

Yeğinsu, I., Şişman, C. ve Saraç, Ö. (2018). "Yeni Medya ve Ötesi: Bağlamlar ve Bağlaçlar", Mod. Ipek Yeğinsu, https://www.youtube.com/watch?v=EW8fVu-SkkQ, Erişim tarihi: 10.11.2018.

Yetkin, Ş. (1993). "Çini", Türkiye Diyanet Vakfı İslâm Ansiklopedisi, https://islamansiklopedisi. org.tr/cini, Erişim tarihi: 18.02.2019.

\section{Görsel Kaynaklar}

Görsel 1. Blombos Mağarası'nda Christopher Henshilwood tarafından bulunan 77.000 yıl öncesi döneme ait tarihi eser, https://www.donsmaps.com/blombos.html, Erişim tarihi: 20.08.2019.

Görsel 2. 13. yüzyıl Elhamra Sarayı bal peteği formundaki tavan işlemesi ve bezemelerdeki radyal motifler, Granada, İspanya, https://ivanpllopis.wordpress.com/2013/09/19/granada-yalhambra/alhambra-palacios-nazaries-cupula-de-la-sala-de-dos-hermanas-iplfoto/, Erişim tarihi: 10.01.2019. 
Görsel 3. Solda Maurits Cornelis Escher'e ait bir grafiğin kristalografik incelemesi sağda "Gündüz ve Gece", 1938, Siyah ve Gri Gravür, 39x67 cm, https://sarkac.org/2018/08/ bezemelerin-gizemli-simetrisi/, Erişim tarihi:10.01.2019.

Görsel 4. Sol LeWitt'e ait boyama talimatı ve "Wall Drawing \#33", 1970, https://www.istanbul sanatevi.com/sanatcilar/soyadi-e/escher-mc/maurits-cornelis-escher-1898-1972/ Erişim tarihi: 10.03.2019. https://www.tate.org.uk/art/artworks/lewitt-a-wall-divided-vertically-into-fifteenequal-parts-each-with-a-different-line-t01766, Erişim tarihi: 10.03.2019.

Görsel 5. Hans Haacke, "Condensation Cube", 1963-1965, Tate Gallery, https://www.semantic scholar.org/paper/Support-within-a-communityLeonard/83f7fe796c54ce971c4a5419c9146987 824ee06/figure/10, Erişim tarihi: 15.02.1019.

Görsel 6. Solda Michael Noll, "Gaussian Quadratic", 1965 ve sağda Georg Nees, "Schotter", 1968, https://www.researchgate.net/figure/Schotter-Gravel-stones-Computer-generatedimage-by-Georg-Nees-1968-1971-The workis_fig8_4732061https://digitalartmuseum.org/ noll/artworks_02.html, Erişim tarihi: 16.04.2019.

Görsel 7. Solda Scot Draves, "Electric Sheep", dijital çalışma, sağda William Latham'a ait dijital fraktal yapılı organik form, http://www.sentientdevelopments.com/2007/01/scott-draves-andevolution-ofart.html,http://www.nemeton.com/static/nemeton/axismutatis/eschaton/ar6 .jpeg, Erişim tarihi: 14.02.2019.

Görsel 8. Casey Reas, "Network A, Process 4", 2009, dijital çalışmasından anlık görüntü ve "Immuring", 2011, Enstalasyon, http://reas.com/network_a_s/,http://reas.com/immuring/, Erişim tarihi: 13.05.2018.

Görsel 9. Rosenkrantz ve Louis Rosenberg, solda "Floraform Chandelier", 2017, sağda “Floraform heykel tasarımı”, 2015, https://n-e-r-v-o-u-s.com/, Erişim tarihi: 01.06.2019.

Görsel 10. Ozan Türkkan, "Bipolar Fraktal”, 2014, dijital video enstalasyon çalışmasından anlık görüntü, http://www.ozanturkkan.com/portfolio/bipolar_fractal, Erişim tarihi: 13.05.2019.

Görsel 11. Harold Cohen'in tasarladığı, "AARON"a ait 1982 ve 1995 yıllarında üretilen çalışmalar, https://www.computerhistory.org/atchm/harold-cohen-and-aaron-a-40-year-collab oration/, Erişim tarihi: 08.08.2019.

Görsel 12. Refik Anadol, "Eriyen Hatıralar", 2018, video enstalasyon, https://bigumigu.com /haber/refik-anadol-dan-en-ozel-veriyi-isliyor-eriyen-hatiralar/, Erişim tarihi: 08.08.2019. 